\title{
SISTEM INFORMASI DISTRIBUSI PENJUALAN AIR CONDITIONER CV. ALI ELECTRICAL BERBASIS JAVA
}

\author{
Ilham Agungi ${ }^{1}$, Imam Sunoto ${ }^{2}$, Intan Mutia $^{3}$ \\ ${ }^{1,2,3}$ Teknik Informatika, Fakultas Teknik dan Ilmu Komputer, Universitas Indraprasta PGRI \\ Jl. Raya Tengah, Gedong, Kec. Ps. Rebo, Kota Jakarta Timur, Daerah Khusus Ibukota Jakarta 13760 \\ $\underline{1 \text { agungilham609@gmail.com, }}, \underline{2}$ raidersimam@gmail.com, $\underline{{ }^{3} \text { as.syifaraa@gmail.com }}$
}

\begin{abstract}
ABSTRAK
Latar belakang dibuatnya program ini untuk membantu sistem yang manual menjadi otomatis. Agar semua system pada CV Ali Electrical terstruktur dengan rapih dan baik. Tujuan dari penelitian ini adalah merancang sistem Penjualan Pada CV Ali Electrical Berbasis Java. dalam melakukan pengolahan data distribusi dan penjualan AC untuk membuat sistem lama menjadi sistem baru dengan memanfaatkan sumberdaya yang ada, baik dari segi perangkat lunak (software), perangkat keras (hardware), maupun pemakai atau pengguna (user). Tujuan dari penelitian ini diantaranya adalah dengan tersedianya sistem pengolahan data yang dapat memberikan kemudahan dalam proses penjualan di perusahaan. Membantu dan meningkatkan kinerja karyawan di perusahaan. Merancang suatu sistem informasi pengolahan data yang dapat memberikan kemudahan dalam melakukan proses/ transaksi penjualan dan dapat meminimalisir kesalahan-kesalahan data yang diakibatkan oleh human error. Metode pengembangan sistem yang digunakan menggunakan metode research and development $(R \& D) /$ forward engineering research. Dimana dalam membangun sistem ini digunakan alat bantu perancangan sistem yaitu Diagram Alir Data (DAD) Konteks, Nol dan Rinci serta dengan menggunakan bahasa pemrograman Java dengan Netbeans dan database MySQL menggunakan XAMPP. Hasil dari peneliti ini adalah Aplikasi ini dapat memudahkan, melancarkan, dan membantu kinerja penjualan CV Ali Electrical dalam melakukan kegiatan-kegiatan distribusi dan penjualan AC.
\end{abstract}

Kata Kunci : Distribusi, Penjualan, Air Conditioner

\begin{abstract}
The purpose of this research is to design a Java-Based Sales system at CV Ali Electrical. in processing AC distribution and sales data to make the old system into a new system by utilizing existing resources, both in terms of software (software), hardware (hardware), as well as users or users (users). The purpose of this research is the availability of a data processing system that can provide convenience in the sales process in the company. Help and improve employee performance in the company. Designing a data processing information system that can provide convenience in processing / sales transactions and can minimize data errors caused by human error. The system development method used is research and development $(R \& D) /$ forward engineering research. Where in building this system used system design tools, namely Context, Zero and Detailed Data Flow Diagrams (DAD) and using the Java programming language with Netbeans and MYSQL database using XAMPP. The results of this research are that this application can facilitate, expedite, and assist the sales performance of CV Ali Electrical in carrying out distribution and sales activities of AC. Key Word: Distribution, Sales, Air Conditioner
\end{abstract}

\section{PENDAHULUAN}

Dalam proses pendistribusian dan penjualan Air Conditioner yang masih dilakukan secara manual, pasti akan sering mengalami masalah terhadap data-data yang masuk (input) dan data-data yang keluar (output) serta dalam prosesnya membutuhkan waktu yang lama, informasi yang kurang akurat, ditambah lagi sering terjadi kesalahan dalam penulisan suatu data dan keamanan dokumennya pun kurang terjamin. Hal ini dapat mengakibatkan perkembangan dan pertumbuhan bidang usaha ini tidak maksimal, oleh sebab itu dibutuhkan satu langkah maju untuk mengatasi berbagai masalah tersebut.

Perkembangan teknologi dapat diterapkan dalam pengolahan data apapun, misalnya saja distribusi dan penjualan ac pada CV. Ali Electrical yaitu dalam bentuk aplikasi pengolahan data kelompok untuk membantu melakukan pengecekan data penjualan AC dengan memanfaatkan teknologi komputer, maka akan mempermudah suatu pekerjaan tertentu seperti pengolahan data menjadi lebih cepat, penghematan ruangan penyimpanan 
data dalam arti mengurangi penumpukan arsip yang tidak diperlukan, serta keputusan yang dibuat menjadi lebih cepat dan relevan. Membantu dan meningkatkan kinerja karyawan di perusahaan. Merancang suatu sistem informasi pengolahan data yang dapat memberikan kemudahan dalam melakukan proses/ transaksi penjualan dan dapat meminimalisir kesalahan-kesalahan data yang diakibatkan oleh human error.

Berbekal permasalahan di atas maka dibuatlah suatu program yang akan dituangkan dalam bentuk tugas akhir dengan judul "Sistem Informasi Distribusi dan Penjualan AC Pada CV Ali Electrical Berbasis Java". Berdasarkan latar belakang masalah di atas penulis dapat mengambil kesimpulan tentang identifikasi masalah sebagai berikut penyimpanan data penjualan belum tertata rapi masih dalam berbentuk berkas, kurang efektifnya dalam pencarian berkas yang masih bersifat manual (berbentuk berkas), sehingga terjadi kesulitan apabila menginginkan pencarian data kembali, Keterlambatan memberikan laporan kepada atasan.

Batasan yang akan penulis bahas dalam penulisan artikel ini yaitu mengubah cara penerapan sistem distribusi dan penjualan $\mathrm{AC}$ yang masih manual menjadi sistem yang terkomputerisasi. Adapun ruang lingkup yang menjadi pemahaman dalam artikel dibatasi oleh penulis. Aplikasi ini menampilkan penyimpanan data Distribusi dan Penjualan, AC dan data transaksi penjualan, Sistem dirancang dengan menggunakan bahasa pemrograman Java Netbeans dan menggunakan database MySQL, Sistem yang dirancang dengan sedemikian rupa sehingga dapat bekerja secara dinamis, yaitu dapat dipergunakan dari tahun ke tahun. Pencarian dan penetapan harga, agar mudah dalam menganalisa, merancang dan mengimplementasikan sistem distribusi dan penjualan AC pada CV Ali Electrical. Selain itu dengan keberadaan perangkat lunak yang dirancang akan dapat menekan berbagai kendala dan ketidak efisienan yang ada selama menggunakan sistem manual.

Kegunaan penelitian ini adalah tersedianya sistem pengolahan data yang dapat memberikan kemudahan dalam proses penjualan di perusahaan, Membantu dan meningkatkan kinerja karyawan di perusahaan, Merancang suatu sistem informasi pengolahan data yang dapat memberikan kemudahan dalam melakukan proses/ transaksi penjualan.

Pengertian sistem menurut Romney dan Steinbart Sistem adalah rangkaian dari dua atau lebih komponen-komponen yang saling berhubungan, yang berinteraksi untuk mencapai suatu tujuan. Sebagian besar sistem terdiri dari subsistem yang lebih kecil yang mendukung sistem yang lebih besar".

Menurut Pengertian sistem menurut Anastasia Diana \& Lilis Setiawati Sistem merupakan "serangkaian bagian yang saling tergantung dan bekerja sama untuk mencapai tujuan tertentu". Menurut Yakub sistem adalah "suatu jaringan kerja dari prosedur-prosedur yang berhubungan, terkumpul bersama-sama untuk melakukan suatu kegiatan atau tujuan tertentu".

Menurut Al-Bahra (2009:51) "Perancangan adalah kemampuan untuk membuat beberapa alternatif pemecahan masalah. Sedangkan menurut Azhar Susanto menjelaskan "Perancangan sistem adalah spesifikasi umum dan terinci dari pemecahan masalah berbasis komputer yang telah dipilih selama tahan analisis" Pengertian Administrasi.

DFD suatu langkah atau metode untuk membuat sebuah perancangan sistem yang mana berorientasi pada alur data yang bergerak ke sebuah sistem lainnya. Seperti halnya DFD adalah sebuah bahasa standar untuk pengembangan software yang dapat menyampaikan bagaimana membuat dan membentuk model-model, tetapi tidak menyampaikan apa dan kapan model yang seharusnya dibuat yang merupakan salah satu proses implementasi pengembangan software. DFD tidak hanya merupakan sebuah bahasa pemrograman visual saja, namun juga dapat secara langsung dihubungkan ke berbagai bahasa pemrograman, seperti JAVA, C++, Visual Basic, atau bahkan dihubungkan secara langsung ke dalam sebuah object-oriented database. Begitu juga mengenai perdokumentasian dapat dilakukan seperti: 
requirements, arsitektur, design, source code, project plan, test, dan prototypes.

Menurut Westriningsih "Netbeans merupakan salah satu IDE yang dikembangkan dengan bahasa pemrograman java". Netbeans mempunyai lingkupan pemrograman yang terintegrasi dalam suatu perangkat lunak yang didalamnya menyediakan pembangunan pemrograman GUI, text editor, compiler, dan interpreter. Netbeans adalah sebuah perangkat lunak open source sehingga dapat digunakan secara gratis untuk keperluan komersial maupun non komersial yang didukung oleh Sun Microsystem.

Menurut Yeni Kustiyahningsih (2011:146) "Database MySQL merupakan sistem manajemen basis data SQL yang sangat terkenal dan bersifat Open Source". MySQL dapat didefinisikan sebagai sistem manajemen database yang merupakan struktur penyimpanan data. Untuk menambah, mengakses dan memproses data yang disimpan dalam sebuah database komputer, diperlukan sistem manajemen database seperti MySQL server.

Menurut Haryadi (2011:1) ada dua pengertian administrasi, yaitu administrasi dalam arti sempit dan administrasi dalam arti luas, yaitu:

a. Administrasi dalam arti sempit

Kegiatan penyusunan dan pencatatan data dan informasi secara sistematis dengan tujuan untuk menyediakan keterangan serta memudahkan memperolehnya secara keseluruhan.

b. Administrasi dalam arti luas

Kegiatan kerja sama yang dilakukan sekelompok orang berdasarkan pembagian kerja sebagaimana ditentukan dalam struktur dengan mendayagunakan sumber daya.

\section{METODE PENELITIAN}

Penelitian dilakukan di CV. Ali Electrical untuk mengumpulkan data, lalu data-data tersebut penulis proses sehingga dapat dimanfaatkan dalam penelitian ini yang berlokasi di Jl. Salak Blok CQ No.14 Perum Bumi Dirgantara Permai RT.004 / RW.013 Jatisari, Jatiasih Kota Bekasi Jawa Barat, Indonesia 16967. Telp: 082192918537. Metode pengumpulan data yang dilakukan oleh penulis untuk mendapatkan data-data serta informasi untuk mendukung penyempurnaan hasil dari penelitian ini antara lain adalah Observasi, Wawancara, dan Metode Kepustakaan Dalam mengembangkan sistem dibutuhkan desain sistem untuk menentukan bagaimana suatu sistem akan menyelesaikan apa yang harus diselesaikan. Poses pengembangan sistem menganalisa kebutuhan sistem, merancang atau mendesain sistem, melakukan kode program, melakukan pengujian dan mengimplementasikannya. Metode pengembangan sistem yang digunakan adalah metode Waterfall.

\section{HASIL DAN PEMBAHASAN}

Analisis Permasalahan

Permasalahan yang dihadapi meliputi:

Penyimpanan data distribusi dan penjualan yang masih kurang efisiensi. Penyimpanan data yang kurang baik, sehingga terjadi kesulitan dalam user pencarian data. Mengatasi kesalahan dalam pencatatan laporan penjualan AC.

Aturan bisnis sistem berjalan pada CV. Ali Electrical adalah sebagai berikut :

1. Proses Distribusi Barang (supplier)

Proses pendistribusian barang atau produk yang dikirim ke CV.Ali Electrical dilakukan oleh Supplier. Setiap supplier yang melakukan pendistribusian barang, direkap dan didata oleh admin untuk melihat kategori barang apa dan qty berapa barang distribusi yang masuk dari supplier yang mengirimkan barang.

2. Proses Barang Masuk

Proses barang masuk ini direkap dan didata juga oleh admin sebagai karyawan CV.Ali Electrical. Saat barang masuk dan sudah diterima,barang akan masuk terlebih dahulu ke gudang yang kemudian akan di cek dan di lihat kualitas serta fisik dari barang yang dikirimkan dari supplier sebagai pendistribusi barang AC.

3. Proses Penjualan Barang

Untuk proses penjualan barang ini nantinya akan didata oleh admin, barang apa yang keluar dari gudang dan barang apa saja yang dipesan oleh pelanggan. Barang yang sudah dipesan harus dibayarkan terlebih dahulu oleh pelanggan, kemudian barangnya baru bisa diterima pelanggan apabila transaksi pembayaran telah selesai. Dalam proses ini 
marketing juga sangat berperan penting karena memasarkan barang atau produk yang sudah tersedia pada perusahaan.

4. Proses Laporan

Dalam proses ini terdapat 2 laporan, yaitu laporan pendistribusian barang oleh supplier terhadap perusahaan, dan laporan penjualan barang terhadap pelanggan atau konsumen yang sudah memesan. Kedua transaksi ini akan direkap dan didata oleh bagian finance untuk selanjutnya akan dilaporkan kepada manager.

5. Diagram Aliran Data (DAD) Konteks, Nol, dan Rinci Sistem Berjalan

1. Diagram konteks sistem berjalan

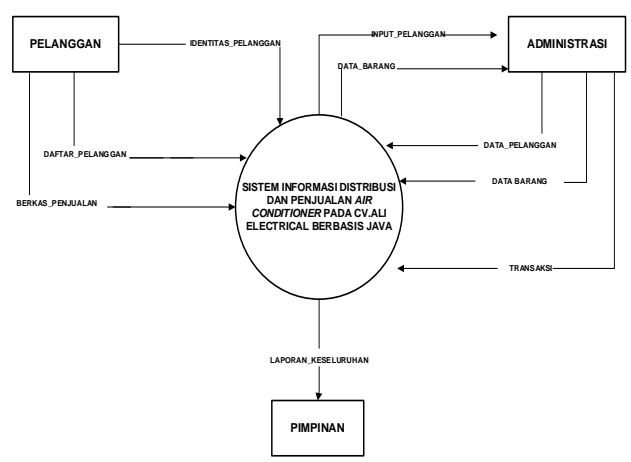

Gambar 1. Diagram konteks sistem berjalan

2. Diagram nol sistem berjalan

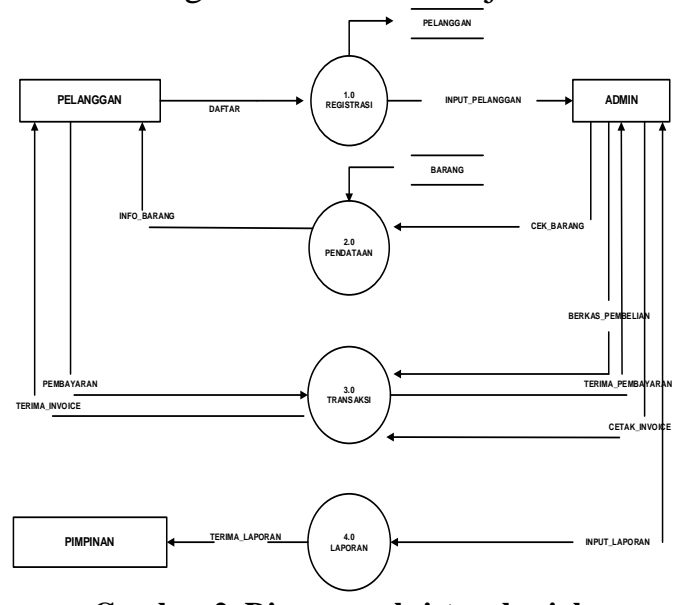

Gambar 2. Diagran nol sistem berjalan

6. Analisis Permasalahan

Masih belum efektifnya pengelolaan pendataan distribusi barang, dan juga pendataan penjualan barang terhadap pelanggan. Pencatatan pada pendataan barang masih menggunakan pendataan manual yang menyebabkan terjadinya kesalahan pada saat mendata atau merekap distribusi dan penjualan barang.

Penyimpanan data distribusi, penjualan terhadap pelanggan, dan data stok barang masih manual dengan bentuk berkas .jumlah transaksi pendistribusian serta penjualan barang terhadap pelanggan, karena pembuatan laporan belum dilakukan secara cepat dan tepat.

Alternatif Penyelesaian Masalah

1. Data diolah dengan menggunakan database dengan aplikasi program, sehingga memudahkan dalam pencatatan , pencarian, dan pendataan data distribusi dan penjualan serta memberikan hasil yang lebih baik.

2. Penyimpanan data disimpan dalam sebuah database pada komputer, sehingga Penyimpanan data barang, distribusi, dan penjualan akan lebih mudah.

3. Informasi tentang berapa jumlah transaksi yang didapat akan mudah didapatkan, karena laporandibuat dengan cepat dan memberikan informasi yang akurat.

Rancangan Sistem yang Diusulkan

1. Aturan Bisnis Sistem yang Diusulkan

a. Pendataan Barang

Proses pendataan barang berhubungan dengan berapa jumlah barang yang diterima oleh perusahaan dari supplier pendistribusian.

b. Proses Distribusi

Proses distribusi berhubungan dengan barang yang dikirim oleh supplier ke perusahaan berdasarkan pesanan.

c. Proses Penjualan

Proses penjualan berhubungan dengan pelanggan yang melakukan pembelian terhadap perusahaan.

d. Proses Transaksi

Proses transaksi berhubungan dengan setiap barang yang sudah diterima dari distribusi (supplier) dan barang yang sudah dijual terhadap pelanggan sesuai dengan tanggal barang masuk/ keluar.

2. Diagram Aliran Data (DAD) Sistem yang Diusulkan

a. Diagram konteks yang diusulkan 


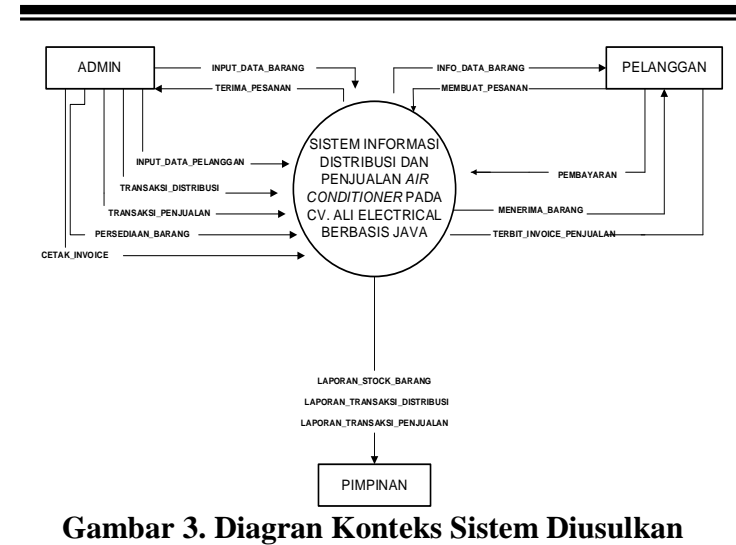

b. Diagram nol yang diusulkan

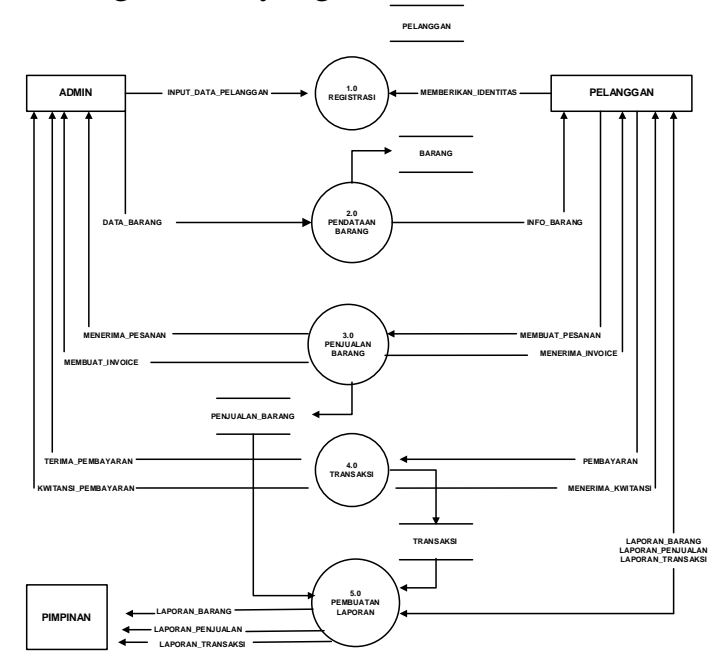

Gambar 4. Diagran Nol Sistem Diusulkan

c. Diagram rinci yang diusulkan

1) Diagram Rinci Proses 1.0

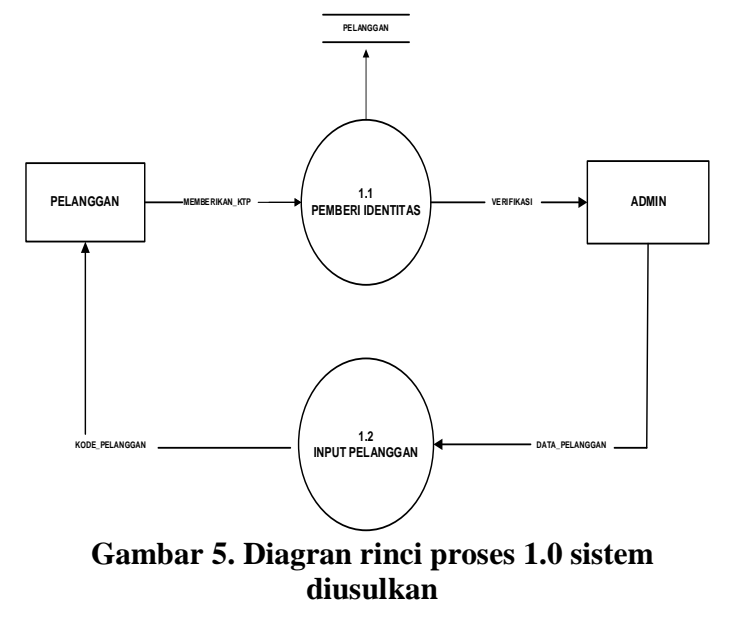

2) Diagram Rinci Proses 2.0

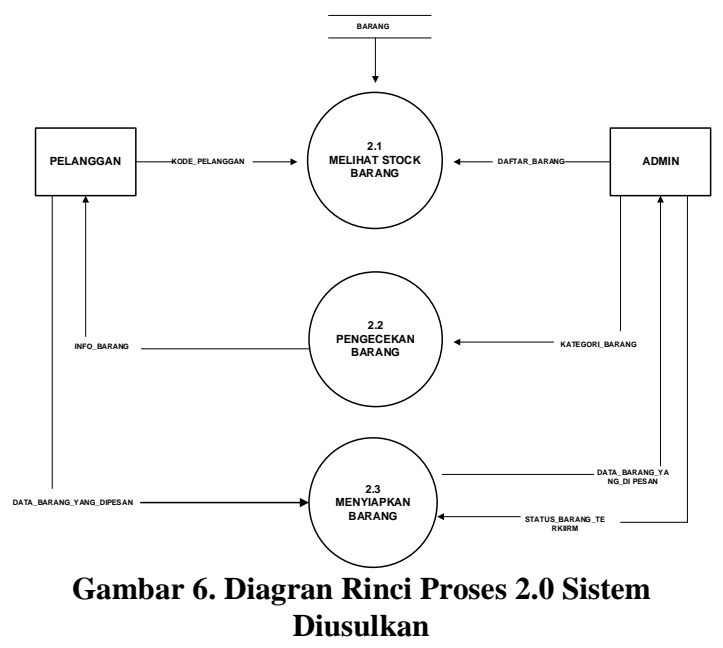

d. Diagram Rinci Proses 3.0

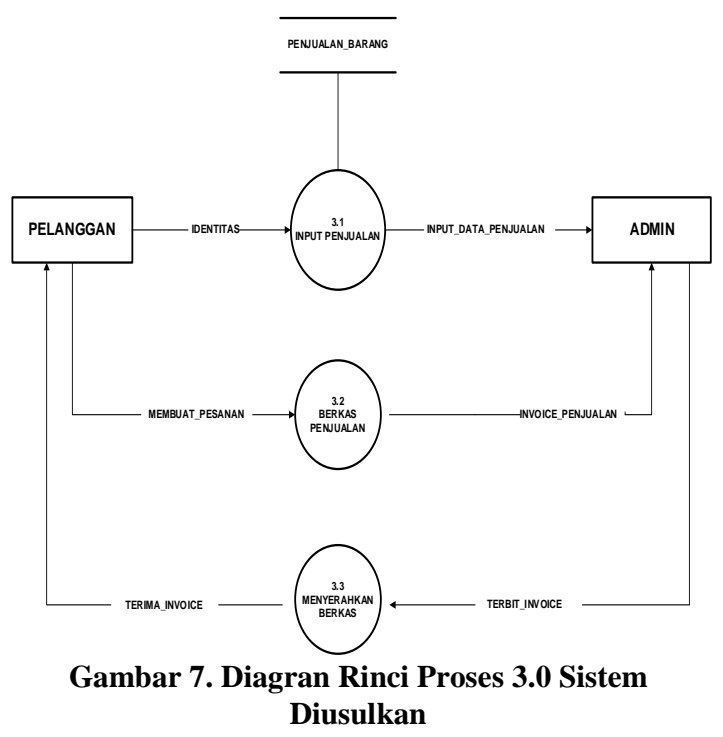

3) Diagram Rinci Proses 4.0

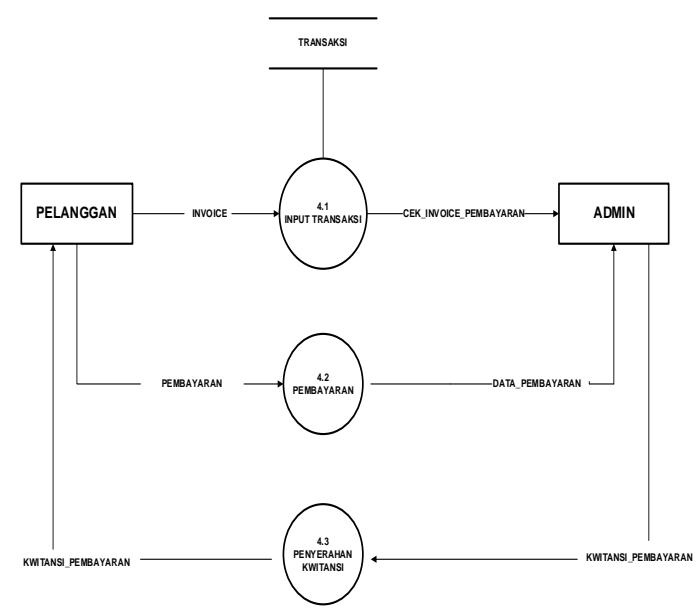

Gambar 8. Diagran Rinci Proses 4.0 Sistem Diusulkan

1143 | Sistem Informasi Distribusi dan Penjualan Air Conditioner pada CV. Ali Electrical Berbasis Java 
4) Diagram Proses 5.0

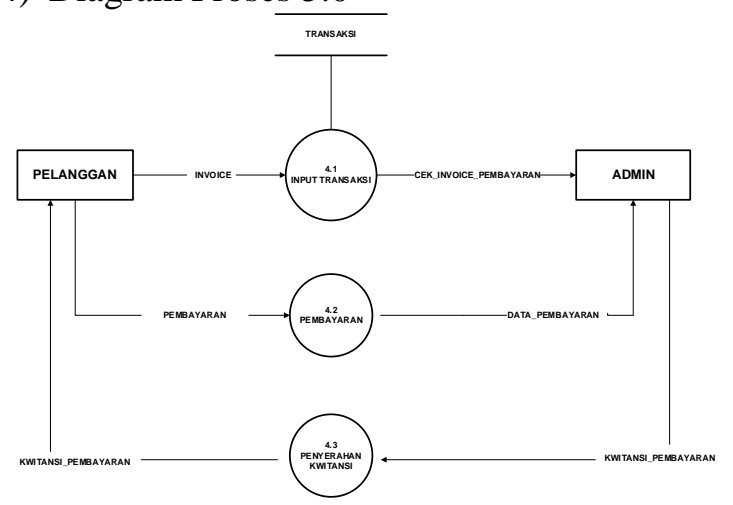

Gambar 9. Diagran Rinci Proses 5.0 Sistem Diusulkan

3. Tampilan Layar

a. Login

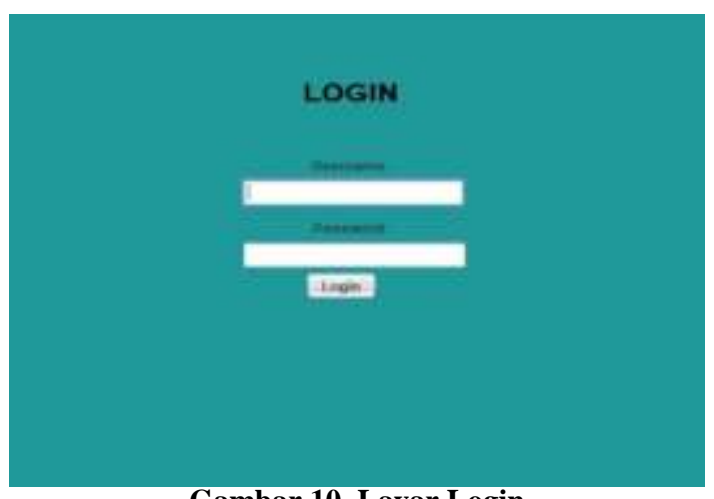

Gambar 10. Layar Login

Pada gambar 10. terdapat menu login untuk masuk kedalam aplikasi, agar dapat melakukan pemprosesan input maupun output barang.

b. Menu

\section{SELAMAT DATANG DI CV. ALI ELECTRICAL Distribusi \& Penjualan AC}

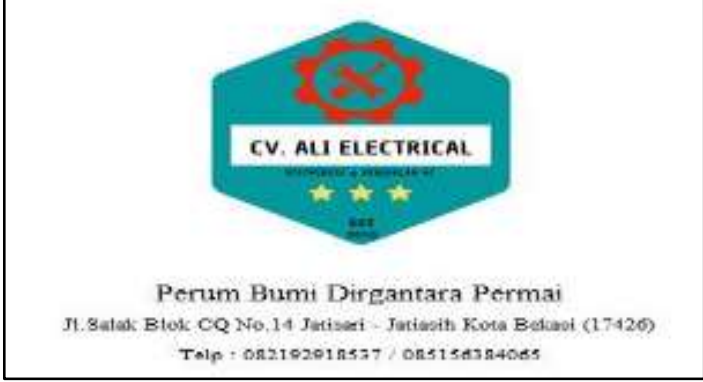

Gambar 11. Layar Menu

Pada gambar 11. ini terdapat tampilan ucapan selamat dating atau juga halaman tampilan depan program sebelum masuk ke dalam. c. Karyawan

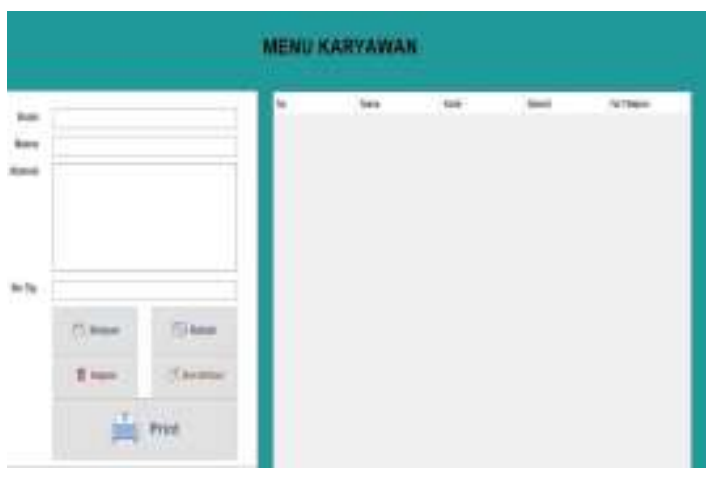

Gambar 12. Layar Data Karyawan

Pada gambar 12. ini terdapat sub menu karyawan dimana didalamnya terdapat kolom-kolom untuk diisi data-data sesuai dengan nama data yang harus dimasukan pada kolom tersebut serta terdapat beberapa tombol yang memiliki fungsi masing-masing diantaranya Simpan untuk menyimpan data didalam database, Ubah untuk mengubah data yang telah tersimpan, Hapus untuk menghapus data yang telah tersimpan, dan Keluar untuk keluar dari sub menu dan kembali ke menu utama

\section{d. Barang}

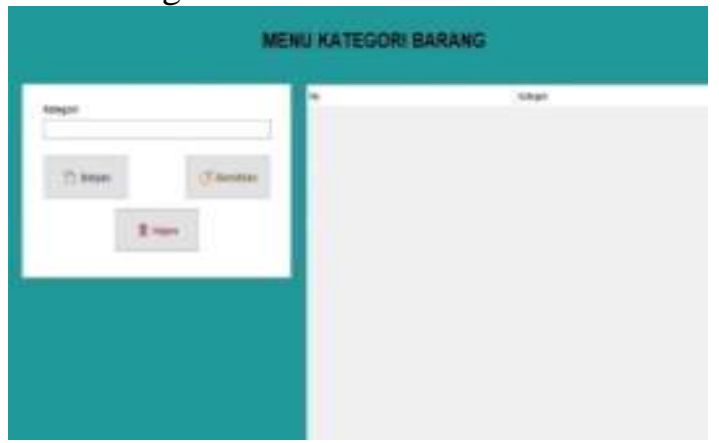

\section{Gambar 13. Layar data barang}

Pada gambar 13. terdapat menu barang untuk melakukan penginputan terhadap barang yang baru masuk, agar di-update pada aksesnya.

\section{e. Pelanggan}

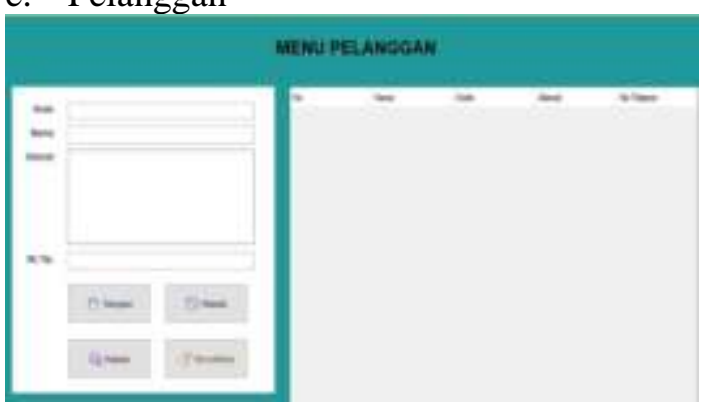

Gambar 14. Layar data pelanggan 
Gambar 14. terdapat sub menu pelanggan yang dapat dilakukan penginputan data sesuai dengan nama kolom yang ada dimana setelah dilakukan penginputan, data yang telah diisi dapat disimpan, diubah, dihapus atau dibersihkan.

\section{f. Distribusi}

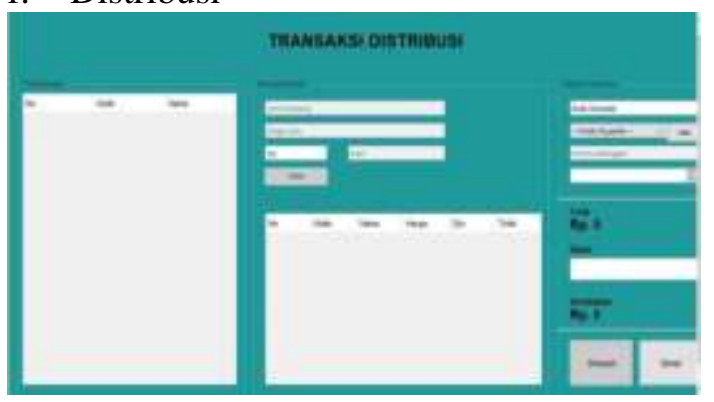

Gambar 15. Layar Distribusi

Gambar 15. merupakan menu transaksi distribusi yang menampilkan detail transaksi dari distribusi penjualan air pada CV Ali Electrical.

\section{g. Transaksi Pelanggan}

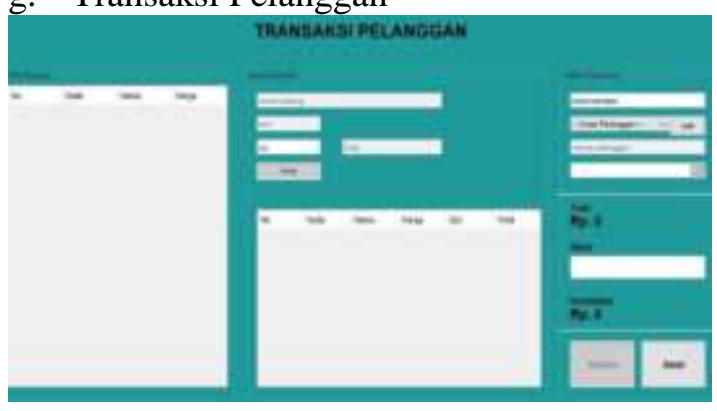

Gambar 16. Layar Transaksi

Gambar 16. merupakan menu transaksi pelanggan yang menampilkan detail data transaksi penjualan barang terhadap pelanggan.

\section{SIMPULAN DAN SARAN}

Dari pembahasan yang menjabarkan tentang sistem distribusi dan penjualan ac berbasis java yang masih dilakukan secara manual tidak dapat memenuhi efisiensi dan efektifitas sebagaimana yang diharapkan. tetapi dengan perancangan yang manual tersebut dan kelemahan yang terdapat pada cara manual dapat diatasi dengan baik. Namun akan lebih baik lagi serta efektif dan efisien bila menggunakan sistem komputerisasi. Dengan perancangan berbasis komputerisasi, akan lebih update dalam pengolahan data pada CV. Ali Electrical, Dengan sistem komputerisasi ketahanan dari data tersebut akan lebih lama, Dengan sistem komputerisasi dapat memberikan informasi yang jelas, cepat, tepat serta efektif dan efisien, Dengan menggunakan sistem tersebut dapat mempermudah pekerjaan pada perusahaan.

Penulis memberikan sedikit saran dengan harapan dapat bermanfaat dalam menjalankan sistem aplikasi distribusi dan penjualan ac pada CV. Ali Electrical untuk mendukung kelancaran sistem tersebut, yakni aplikasi pada CV. Ali Electrical dapat dikembangkan kembali dalam hal design atau penambahan database sesuai kebutuhan pengolahan data.

\section{DAFTAR PUSTAKA}

Adisasmita, S. A. (2014). Pengantar Perencanaan Transportasi. 262. https://www.pustaka.ut.ac.id/lib/pwk141 03-perencanaan-transportasi/

Hutahaean, J. (2015). Konsep Dasar Sistem Informasi. Konsep Dasar Sistem Informasi, 1-36.

Kadir, A. (2014). Pengenalan sistem informasi edisi revisi. Yogyakarta: Andi, 2.No Title. Edisi Revisi, January. https://doi.org/10.13140/2.1.2637.6328

Roger S. Pressman. (2012). Rekayasa Perangkat Lunak Buku 1 Edisi 7. 260.

Satzinger Jackson Burd Staff. (2009). Systems Analysis and Design in a Changing World 5th (Fifth) - Chapter 2.

Silalahi, U. (2011). Asas-Asas Manajemen. Asas-Asas Manajemen, 1-23.

Sugiyono. (2013). Sugiyono Metode Penelitian Kuantitatif Kualitatif. Metode Penelitian Kuantitatif Kualitatif, 6.

Sutabri, T. (2012). Konsep Sistem Informasi. Jurnal Administrasi Pendidikan UPI, 3(1), 248.

Sutarman. (2021). Buku pengantar Teknologi Informasi (Issue May).

Swastika, W., Nur, A. W., \& Kelana, O. H. (2019). Monitoring Ruangan Untuk Deteksi Manusia Berbasis CNN Dengan Fitur Push Notification. Teknika, 8(2). https://doi.org/10.34148/teknika.v8i2.1 66 